\title{
Daya Antimikrobia Sarang Lebah Madu Trigona spp terhadap Mikrobia Patogen
}

\author{
RENITA YULIANA ${ }^{1 *}$, ENDANG SUTARININGSIH ${ }^{2}$, HARRY BUDI SANTOSO ${ }^{3}$, \\ KRESNO AGUS HENDARTO ${ }^{3}$, SEPTIANTINA DYAH RIENDRASARI ${ }^{3}$ \\ ${ }^{1,2}$ Program Pascasarjana Fakultas Biologi Universitas Gadjah Mada \\ ${ }^{2}$ Professor Mikrobiologi Universitas Gadjah Mada \\ ${ }^{3}$ Balai Penelitian Teknologi Hasil Hutan Bukan Kayu Mataram \\ *email: tata_renjuly@ymail.com
}

Manuscript received: 14 Desember 2014 Revision accepted: 25 Januari 2015

\begin{abstract}
Potensi sarang lebah madu Trigona spp untuk menghasilkan antimikrobia sangat tinggi, tidak hanya pada bagian propolis, melainkan keseluruhan bagian dari sarang yang terdiri dari kantong madu, kantong polen, kantong telur, dan penutup sarang. Sarang lebah madu Trigona spp berfungsi sebagai tempat perlindungan lebah dari predator maupun parasit seperti fungi, jamur dan virus. Sarang lebah madu Trigona spp dapat dijadikan alternatif sumber antimikrobia alami sehingga diperlukan penelitian untuk mendeteksi aktivitas tersebut. Tujuan dari penelitian ini meneliti daya antimikrobia yang dilepaskan sarang lebah madu Trigona spp terhadap pertumbuhan mikrobia dan meneliti komponen kimia utama yang terkandung dalam sarang lebah madu Trigona spp. Metode untuk ekstraksi sarang menggunakan ethanol $70 \%$ secara maserasi dan uji antimikrobia yang terdiri dari antibakteri dan antifungi dilakukan dengan metode difusi sumur. Rancangan penelitian yang digunakan dalam bentuk rancangan acak lengkap (RAL). Data yang diperoleh dari hasil pengamatan di laboratorium dianalisis dengan menggunakan statistik parametrik yaitu One way ANOVA. Hasil penelitian menunjukkan aktivitas antimikrobia sarang lebah madu Trigona spp berpengaruh menghambat pertumbuhan mikrobia patogen uji dengan konsentrasi hambat minimal $1 \%(\mathrm{v} / \mathrm{v})$. Senyawa kimia utama sebagai antimikrobia berasal dari asam lemak dan fenol.
\end{abstract}

Keywords: antimikrobia, sarang lebah, Trigona spp, mikrobia patogen

\section{LATAR BELAKANG}

Produk peternakan Trigona spp yang telah banyak dimanfaatkan adalah madu dan propolis. Propolis merupakan bagian dari sarang lebah madu Trigona spp yang terdiri dari senyawa yang merupakan bahan resin komplek yang dihasilkan oleh lebah madu dari eksudat tanaman (Selvan\&Prabhu, 2010). Penelitian sebelumnya tentang propolis atau penutup sarang yang merupakan bagian dari sarang lebah madu Trigona spp membuktikan bahwa propolis memiliki potensi sebagai sumber antimikrobia seperti aktivitas antibakteri mampu menghambat pertumbuhan Campylobacter spp (Fatoni et al., 2008).

Berbagai penelitian telah dilakukan untuk mendapatkan antimikrobia alami dari hasil peternakan Trigona spp selain propolis, salah satunya adalah sarang lebah. Sarang lebah merupakan tempat perlindungan bagi koloni lebah dari serangan bakteri, jamur, virus maupun predator, serta sebagai tempat produksi madu, bee pollen, dan tempat tumbuh kembang telur lebah. Kondisi sarang lebah sangat mempengaruhi kualitas madu dan yang dihasilkan. Madu pada umumnya terbebas dari mikrobia patogen. Penurunan kualitas madu dan bahkan tidak layak untuk dikonsumsi disebabkan oleh keberadaan bakteri tertentu dan didominasi oleh Bacillus $s p$ pada sarang lebah (Perez et al., 2013).

Potensi sarang lebah madu Trigona spp sebagai sumber antimikrobia sangat menarik untuk diteliti, karena sebagai akibat dari keberadaan antimikrobia tersebut kualitas madu dan kesterilan sarang dapat terjaga. Kandungan senyawa pada sarang lebah madu berfungsi sebagai pelindung dan penentu kualitas madu antara lain flavonoid yang merupakan senyawa fenol alami dan bees wax (Ra'ed J et al., 2008). Berdasar kandungan senyawa tersebut, bagian sarang lebah madu Trigona spp telah diteliti dan digunakan sebagai antibakteri Streptococcus mutans (Sabir, 2005). Bagian sarang lebah madu Trigona spp yang berpotensi sebagai antimikrobia tidak hanya terdapat pada bagian penutup sarang atau propolis, melainkan terdapat pula pada bagian kantong polen, kantong madu, dan kantong telur. Bagian dari sarang lebah madu memiliki komponen senyawa yang berbeda sebagai agen antimikrobia.

Jenis antimikrobia yang dihasilkan sarang lebah madu termasuk kelompok antibiotik tetrasiklin, streptomisin, sulfonamid, tylosin, erytromisin, lincomisin, dan kloramfenikol (Reybroeck et al., 2012). Hal tersebut menunjukkan bahwa sarang lebah madu berpotensi digunakan sebagai antibiotik untuk menekan sampai mematikan berbagai macam bakteri patogen sehingga kualitas madu terjaga. Senyawa agen antimikrobia sarang lebah madu Trigona spp dapat dijadikan sebagai sumber antimikrobia alami yang berasal dari alam.

Keunikan dari sarang lebah madu Trigona spp adalah selalu dalam kondisi steril. Hal ini disebabkan karena adanya senyawa antimikrobia yang terkandung didalamnya. Senyawa-senyawa yang terkandung dalam 
sarang lebah madu Trigona spp yang berpotensi sebagai antimikrobia alami dapat digunakan sebagai bahan pengobatan alternatif alami disamping adanya jenis obat antibiotik komersial yang beredar dipasaran. Penelitian ini bertujuan untuk mengetahui daya antimikrobia yang dilepaskan sarang lebah madu Trigona spp terhadap pertumbuhan mikrobia dan meneliti komponen kimia yang terkandung dalam sarang lebah madu Trigona spp sebagai sumber agen antimikrobia.

Perbedaan penelitian ini dengan penelitian sebelumnya, misalnya yang dilakukan oleh Sabir (2005) dan Fatoni et al (2008) yang memfokuskan pada bagian propolis atau penutup sarang yang merupakan salah satu bagian dari sarang lebah madu Trigona spp serta Andualem (2013) yang memfokuskan madu sebagai agen antimikrobia. Penelitian ini memfokuskan pada bagian keseluruhan sarang lebah madu Trigona spp yang terdiri dari kantong madu, kantong polen, kantong telur, dan penutup sarang sebagai agen antimikrobia. Penelitian ini juga memfokuskan pada mikrobia yang mendominasi sarang lebah madu Trigona spp.

\section{METODE}

Sampel yang digunakan untuk penelitian adalah sarang lebah Trigona spp yang terdiri dari kantong madu, kantong polen, kantong telur dan penutup sarang diambil saat panen madu sebagai sumber antimikrobia. Pengambilan sampel dilakukan secara purposive sampling dengan kriteria jumlah stup lebih dari 100, produksi tinggi, dan budidaya yang dilakukan lebih dari 10 tahun.

Lokasi pengambilan sampel di Kabupaten Lombok Barat, Kabupaten Lombok Timur, dan Kabupaten Lombok Utara. Sampel diambil pada bulan November 2014. Kondisi lingkungan tempat pengambilan sampel, sarang lebah madu Trigona spp ternaungi dari paparan sinar matahari dengan suhu antara $30-32^{\circ} \mathrm{C}$ dan kelembaban antara 63-65\%.

Sample Bahan yang digunakan dalam penelitian ini adalah: sarang lebah Trigona spp, mikrobia uji yang digunakan adalah kultur murni Staphylococcus aureus, Pseudomonas aeruginosa, dan Candida albicans yang berasal dari Rumah Sakit Provinsi Nusa Tenggara Barat.

Media pertumbuhan mikrobia uji. Media Nutrient Agar (NA) untuk pertumbuhan isolat bakteri uji, yaitu Staphylococcus aureus dan Pseudomonas aeruginosa dengan komposisi $(\mathrm{g} / \mathrm{L})$ berupa beef extract $3 \mathrm{~g}$, pepton 5 g, dan agar 15 g. Media Peptone Glucose Yeast Extract Agar (PGYA), dengan komposisi (g/L) berupa pepton (Oxoid) 5 gram $/ \mathrm{L}$, yeast extract (Oxoid) 5 gram $/ \mathrm{L}$, glukosa (Difco) 5 gram/L, dan agar 16 gram/L. Media dasar untuk uji antimikrobia adalah Mueller Hinton Agar (MHA) dengan $\mathrm{pH} 7,3 \pm 0,1$ pada suhu $25^{\circ} \mathrm{C}$, dengan komposisi $(\mathrm{g} / \mathrm{L})$ berupa beef extract $(300 \mathrm{~g})$, casein hidrolysate $(17,5 \mathrm{~g})$, amilum (1,5 g), dan agar (17 g). Media untuk uji antifungi adalah media Peptone Glucose Yeast Extract Agar (PGYA), dengan komposisi (g/L) berupa pepton 5 gram $/ \mathrm{L}$, yeast extract 3 gram $/ \mathrm{L}$, glukosa 5 gram/L, dan agar 20 gram/L. Sterilisasi media dengan autoclave pada suhu $121^{\circ} \mathrm{C}$ selama 15 menit (Atlas, 2010). Antimikrobia pembanding yang digunakan untuk uji antibakteri adalah tetrasiklin $500 \mathrm{mg}$. Antimikrobia pembanding yang digunakan untuk uji antifungi adalah ketoconazole $200 \mathrm{mg}$.

Senyawa kimia yang dibutuhkan untuk ektraksi adalah etanol $70 \%$ sebanyak $2 \mathrm{~L}$ dan propilen glikol (Merck) sebanyak $50 \mathrm{~mL}$. Senyawa uji C total $10 \mathrm{~mL}$ K2Cr2O7 1 $\mathrm{N}, \mathrm{H}_{2} \mathrm{SO}_{4} 96 \% 7,5 \mathrm{~mL}$, dan akuades $200 \mathrm{~mL}$. Senyawa uji fenol adalah acetonitril $70 \% 14 \mathrm{~mL}$ dan standar fenol $0,25 \%$. Senyawa uji komponen kimia sebagai agen antimikrobia alkohol 99\%, gas helium, crossbond 5\% dyhenyl, 95\% dimethyl polysiloxane.

Prosedur kerja dalam penelitian di Laboratorium meliputi: ekstraksi Sarang lebah Madu Trigona spp dengan metode maserasi. Sarang lebah yang masih segar terdiri dari kantong madu, kantong polen, kantong telur, dan penutup sarang masing-masing sebanyak $25 \mathrm{~g}$ dan sarang lebah madu utuh terdiri dari kantong madu, kantong polen, kantong telur, dan penutup sarang dicampur sebanyak $25 \mathrm{~g}$. Bagian masing-masing sarang lebah dipotong-potong, kemudian dihaluskan dengan penambahan pelarut etanol $70 \%$ sebanyak $250 \mathrm{ml}$ (perbandingan antara sampel:pelarut yaitu, 1:10) (Pujirahayu, et al., 2014). Sarang lebah yang sudah dihaluskan dengan pelarut ethanol $70 \%$ disimpan selama 24 jam (Selvan dan Prabhu, 2010) dengan diletakkan diatas shaker pada suhu $40^{\circ} \mathrm{C}$ dan dihindarkan dari cahaya. Campuran sarang lebah dengan ethanol $70 \%$ yang sudah didiamkan selama 24 jam disaring dengan penyaring dan corong steril untuk memisahkan filtrat dari endapan/ampas ke dalam erlenmeyer, kemudian diuapkan hingga mengering. Sisa/ ampas sarang lebah madu Trigona spp diekstraksi kembali sampai pelarut alkohol tidak berwarna (bening). Ekstrak sarang lebah madu Trigona spp yang telah diperoleh ditambahkan propilen glikol dengan perbandingan 1:1 yang akan digunakan sebagai sampel uji antimikrobia.

Analisis Kimia Sarang Lebah Madu Trigona spp yaitu, menguji $\mathrm{pH}$ sampel sarang lebah madu Trigona spp diukur menggunakan $\mathrm{pH}$ meter. Analisis karbon (C) total Sarang Lebah Madu Trigona spp menggunakan metode Walkley \& Black (Rahmayanti et al., 2013). Sarang lebah madu sebanyak 0,05 gram dicampur dengan $10 \mathrm{~mL}$ $\mathrm{K}_{2} \mathrm{Cr}_{2} \mathrm{O} 7 \quad 1 \mathrm{~N}$ dan 7,5 $\mathrm{mL} \mathrm{H}_{2} \mathrm{SO}_{4} 96 \%$, kemudian dipanaskan diatas waterbath selama 2 jam. Campuran tersebut diencerkan menggunakan akuades sampai dengan tanda batas labu $100 \mathrm{~mL}$, mendiamkan campuran selama 24 jam. Pengukuran dilakukan menggunakan spektrofotometer pada $\lambda 561 \mathrm{~nm}$. Blangko dibuat dengan reagen yang sama tanpa penambahan sampel.

Perhitungan kadar C-total=

$C(\%)=\left(\left(\frac{\text { absorbance sampel }}{\text { rata }- \text { rata absorbance standar }}\right) \times\right.$ rata - rata PPM standar $)$

Analisis Fenol Sarang Lebah Madu Trigona spp dengan HPLC. Sampel sarang lebah madu sebanyak $2 \mathrm{~g}$ ditambah $14 \mathrm{~mL}$ acetonotril $70 \%$, kemudian didiamkan 24 
jam. Sampel disaring menggunakan kertas saring (Whatmann No.41) dan penyaring PVDF (Milipore). Pengukuran kadar fenol menggunakan HPLC.

Perhitungan kadar fenol:

$$
\text { Kadar Fenol }(\%)=\frac{\left(\frac{\text { Luas area sampel }}{\text { Luas area standar }}\right) \times \% \text { standar } \times 14}{\text { berat sampel }}
$$

Analisis komponen sarang lebah madu Trigona spp menggunakan metode gas chromatography-mass spectrometry (GCMS). Sampel sarang lebah madu sebanyak $1 \mathrm{~g}$ diekstraksi menggunakan alkohol absolut selama 24 jam. Volume sampel yang digunakan untuk analisis GC-MS sebanyak $1 \mu \mathrm{L}$ (Kumar et al., 2009). Fase gerak yang digunakan berupa gas helium dengan eluen Crossbond 5\% diphenyl, 95\% dimethyl polysiloxone.

Deteksi daya antimikrobia sarang lebah

\section{Pemurnian Kultur Bakteri}

Biakan murni Staphylococcus aureus dan Pseudomonas aeruginosa dari Rumash Sakit Provinsi Nusa Tenggara Barat sebagai model dimurnikan dengan cara atau teknik kultur sel tunggal dengan teknik goresan kembali pada media NA, sedangkan Candida albicans ditumbuhkan pada media PGYA, diinkubasi selama 24 jam pada suhu $37^{\circ} \mathrm{C}$. Koloni yeast atau bakteri yang tumbuh terpisah diambil 1 ose dan dipindahkan ke media NA miring dan PGYA miring sebagai kultur murni.

\section{Uji Daya Antimikrobia Sarang Lebah Madu Trigona spp terhadap mikroba patogen}

Preparasi inokulan uji dengan cara menginokulasikan 1 ose kultur murni mikrobia kedalam $\mathrm{NaCl} 0,9 \%$ kemudian divortex hingga homogen. Biakan sebanyak $50 \mu \mathrm{l}$ diambil untuk uji antimikrobia. Uji daya antimikrobia sarang lebah dilakukan dengan menggunakan metode difusi (Jawetz et al., 2010). Suspensi sel mikrobia uji sebanyak $50 \mu \mathrm{l}$ diinokulasikan pada media MHA dan PGYA (ketebalan 0,5 cm $(20 \mathrm{~mL})$ ) secara taburan (pour plate). Media dilubangi untuk membuat sumuran dengan diameter $7 \mathrm{~mm}$ sebagai tempat ekstrak sarang lebah. Sebanyak 100 $\mu$ sampel sarang lebah dimasukkan ke dalam masingmasing sumuran, inkubasi selama 24 jam pada suhu $37^{\circ} \mathrm{C}$. Pertumbuhan mikrobia diamati terutama yang tumbuh disekitar sumuran, apabila terbentuk zona bening disekitar sumuran maka hasil dinyatakan positif. Pengamatan terbentuknya zona bening diukur menggunakan jangka sorong.

\section{Analisis Konsentrasi Hambat dan Bunuh Minimum}

Uji konsentrasi hambat minimum dan uji konsentrasi bunuh minimum menggunakan metode difusi pada media MHA dan PGYA dengan ketebalan $0,5 \mathrm{~cm}(20 \mathrm{~mL})$. Uji KHM dan KBM dilakukan menggunakan ekstrak yang telah diperoleh pada konsentrasi $1 \%$ sampai dengan $10 \%$. Kontrol positif yang digunakan larutan baku tetrasiklin $500 \mathrm{mg}$ produksi kimia farma untuk bakteri dan ketoconazole $200 \mathrm{mg}$ produksi OGB dexa untuk yeast. Isolat uji diinokulasikan kedalam media sebanyak $50 \mu \mathrm{l}$ secara pour plate. Media yang telah diinokulasikan suspensi mikroba dilubangi dengan diameter $7 \mathrm{~mm}$. Sumuran pada media digunakan untuk memasukkan sampel sarang lebah dengan konsentrasi yang berbeda sebanyak $100 \mu \mathrm{l}$. Inkubasi pada suhu $37^{\circ} \mathrm{C}$ selama 24 jam. Pengamatan terbentuknya zona bening diukur menggunakan jangka sorong.

Data yang diperoleh dari hasil pengamatan di laboratorium dianalisis dalam bentuk Rancangan Acak lengkap (RAL). Data yang diperoleh dianalisis dengan ANOVA (Analysis of Variance) dengan tingkat kepercayaan $95 \%$ dan taraf $\alpha 0,05$.

\section{HASIL DAN PEMBAHASAN}

Metode ekstraksi sarang lebah madu Trigona spp menggunakan metode maserasi. Pelarut yang digunakan adalah alkohol $70 \%$ yang merupakan pelarut semipolar yang dapat mengekstraksi senyawa dengan kepolaran rendah. Ekstraksi propolis menggunakan alkohol $70 \%$ menghasilkan rendemen yang paling tinggi (Pujirahayu et al, 2014; Selvan\&Prabhu, 2010). Alkohol memiliki titik didih yang rendah dan mudah untuk menguap, sehingga dapat memperkecil tercampurnya alkohol dalam ekstrak. Penggunaan alkohol $70 \%$ dapat melarutkan sarang lebah madu Trigona spp, dan memperkecil terlarutnya lilin/ wax (beeswax) yang merupakan pengganggu dalam ekstraksi (Pujirahayu et al, 2014). Penggunaan propilen glikol sebagai pelarut ekstrak karena propilen glikol dapat melarutkan ekstrak sarang lebah madu Trigona spp dan tidak memiliki kemampuan sebagai agen antimikrobia.

Ekstrak sarang lebah madu Trigona spp berwarna cokelat hingga cokelat tua dan berbentuk pasta (gambar 1) dengan pH antara 4-5. Warna ekstrak dipengaruhi oleh adanya senyawa fenolik dan flavonoid. Rendemen hasil ekstraksi sarang lebah madu Trigona spp, yaitu kantong polen $47,8 \%$, kantong madu $49,74 \%$, kantong telur $40,92 \%$, penutup sarang $39,05 \%$, dan campuran keseluruhan sarang (mix) 42,74\%. Hasil ekstraksi sarang lebah madu Trigona spp tidak lebih dari 50\% karena kandungan lilin/ wax yang tinggi yang memiliki kadar karbon tinggi, yaitu kantong polen $29,54 \%$, kantong madu $37,69 \%$, kantong telur $18,85 \%$, penutup sarang $26,56 \%$, dan campuran keseluruhan sarang (mix) 33,33\%.

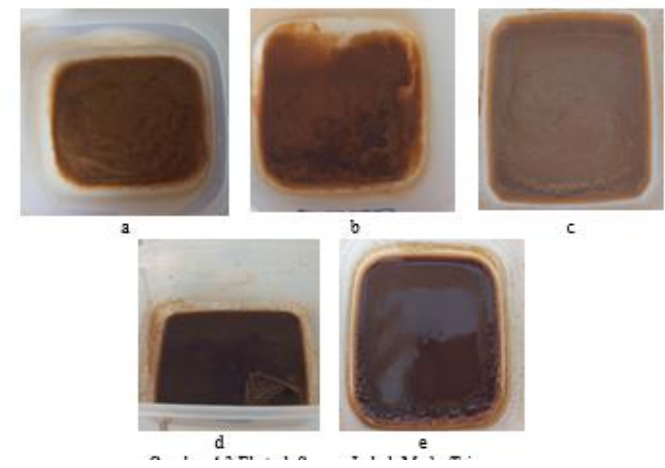

Gambar 4.3 Ekstrak Sarang Lebah Madu Trigona spp (a) Ekstrak kantong madu, (b) ekstrak kantong polen, (c) ekstrak kantong telur, (d) ekstrak penutup sarang, dan (e) ekstrak sarang lebah madu keseluruhan 
Sarang lebah madu Trigona spp memiliki kemampuan dalam menghambat dan membunuh mikrobia uji yaitu Staphylococcus aureus, Pseudomonas aeruginosa, dan Candida albicans. Luas zona bening yang terbentuk dapat dilihat pada Gambar 1. Aktivitas antimikrobia terbesar terdapat pada kantong polen dan aktivitas terkecil terdapat pada penutup sarang, jika dilihat dari terbentuknya zona bening. Kantong polen memiliki daya penghambatan yang lebih tinggi terhadap Candida albicans dibandingkan penghambatan terhadap bakteri Staphylococcus aureus dan Pseudomonas aeruginosa.

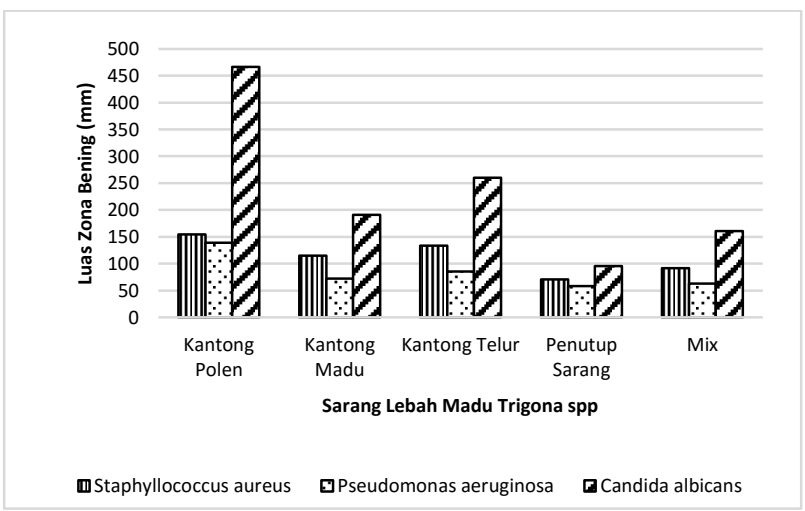

Gambar 1. Luas Zona Bening Uji Antimikrobia Sarang Lebah Madu Trigona spp

Hasil analisis statistika menunjukkan sarang lebah madu Trigona spp berpengaruh terhadap pertumbuhan mikrobia uji (Staphylococcus aureus, Pseudomonas aeruginosa, dan Candida albicans). Hasil uji konsentrasi hambat minimum sarang lebah madu Trigona spp terhadap mikrobia uji yang diperoleh menunjukkan nilai KHM yang diperoleh yaitu $1 \%(\mathrm{v} / \mathrm{v})$, artinya konsentrasi sarang lebah madu Trigona spp $1 \%$ mampu menghambat pertumbuhan mikrobia patogen uji. Penentuan nilai KHM berfungsi untuk menentukan konsentrasi terendah dari ekstrak sarang lebah madu Trigona spp dalam menghambat pertumbuhan mikrobia patogen uji. Konsentrasi hambat minimum dipengaruhi oleh banyaknya senyawa aktif sebagai agen antimikrobia. Bagian sarang lebah madu Trigona spp konsentrasi $1 \%$ yang memiliki luas zona hambat terkecil terdapat pada penutup sarang, yaitu $63,16 \mathrm{~mm}$.

Berdasarkan hasil zona bening/ zona hambat yang terbentuk, dapat disimpulkan bahwa sarang lebah madu Trigona spp memiliki potensi sebagai antimikrobia alami untuk menghambat sekaligus membunuh mikrobia patogen. Sifat dari antimikrobia sarang lebah madu Trigona spp adalah bakteriosidal yang artinya antimikrobia tersebut memiliki kemampuan untuk membunuh mikrobia patogen uji. Senyawa aktif yang berperan dalam penghambatan pertumbuhan mikrobia patogen adalah gugus hidroksil yang menyebabkan perubahan komponen organik dan transport nutrisi sehingga mengakibatkan efek toksik pada mikrobia patogen (Cushnie\&Lamb, 2005; Carlo et al,1999), selain itu juga menghambat spora patogen pada fungi.

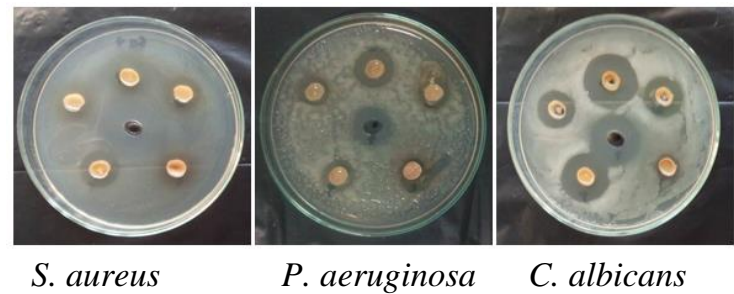

Gambar 2. Hasil Uji Antimikrobia

Senyawa antimikrobia didominasi oleh asam lemak, baik asam lemak jenuh maupun asam lemak tak jenuh. Senyawa 2-(9,12-octadecadienyloxy) atau Cis-9,12Octadecadienyyloxy ethanol dalam kantong polen memiliki kemampuan sebagai antimikrobia (Lakshmi\&Bai, 2015). Senyawa lauric acid dan myristic acid dalam kantong telur dan oleic acid yang terdapat dalam sarang lebah madu Trigona spp merupakan antibakteri untuk menghambat pertumbuhan bakteri gram positif seperti Staphylococcus aureus (Batovska et al., 2009; Desbois et al, 2013). Senyawa decanoic acid (capric) dan asam palmitat yang terdapat dalam semua bagian sarang lebah madu Trigona spp serta lauric acid dan myristic acid dalam kantong telur merupakan agen antifungi yang dapat menghambat pertumbuhan Candida albicans, bakteri Gram positif dan bakteri Gram negatif (Pohl et al., 2011; Karlova et al., 2010; Karbara et al., 1972). Heptadecen-8-carbonic acid dalam kantong polen memiliki kemampuan sebagai agen antimikrobia. Kandungan coconut oil murni dalam sarang lebah madu Trigona spp merupakan kandungan senyawa lain yang merupakan agen antimikrobia, baik bakteri Gram positif maupun Gram negatif (Sia et al., 2010). Cococnut oil juga dapat menghambat pertumbuhan Candida albicans dengan konsentrasi minimum 25\% (Ogoblu et al., 2007).

Kandungan senyawa fenolik (Phenolic acid, flavonoid, dan tanin) yang terdapat dalam sarang lebah madu Trigona spp dapat menghambat pertumbuhan bakteri Gram positif seperti Staphylococcus dan Enterococcus juga bakteri Gram negatif seperti Escherichia coli dan Proteus mirabilis (Alves et al., 2013). Senyawa fenolik dapat menghambat pertumbuhan Escherichia coli dengan konsentrasi minimum 1,25 mg/ml (Nitiema et al., 2012). Kadar fenol dalam sarang lebah madu Trigona spp dalam sarang yaitu; kantong polen $0 \%$; kantong madu $0,22 \%$; kantong telur $0,87 \%$; dan penutup sarang $0,27 \%$. Kadar fenol tertinggi terdapat pada kantong telur. Hasil uji fenol menggunakan HPLC kantong polen menunjukkan hasil $0 \%$, akan tetapi pada uji GC-MS menunjukkan bahwa senyawa penol terkandung didalam kantong polen. Hal tersebut disebabkan karena pemisahan kantong polen dengan polen menggunakan air yang menyebabkan sebagian besar fenol ikut terlarut didalam air. Hexatriocontane merupakan minyak esensial lain dalam kantong polen erperan sebagai antimikrobia dapat menghambat pertumbuhan bakteri Gram positif (S.aureus) dan Gram negatif (Bacillus) serta fungi strain A.niger. 
Mekanisme asam lemak sebagai antimikrobia yang dapat menghambat atau membunuh dipengaruhi oleh beberapa faktor seperti konsentrasi antimikrobia, mikrobia target, dan keadaan fisiologi mikrobia seperti suhu dan $\mathrm{pH}$ (Desbois, 2012). Antimikrobia asam lemak memiliki sebaran spektrum yang luas untuk menghambat pertumbuhan bakteri Gram positif, bakteri Gram negatif maupun yeast. Antimikrobia asam lemak memiliki kelebihan lain seperti; relatif lebih stabil, tidak menimbulkan korosi, konsentrasi yang digunakan sampai milimolar, lebih berpengaruh besar pada $\mathrm{pH}$ rendah, dan toksisitasnya rendah terhadap sel non-mikrobia (Desbois,2012).

\section{KESIMPULAN}

Rendemen hasil ekstraksi sarang lebah madu Trigona spp, yaitu kantong polen 47,8\%, kantong madu 49,74\%, kantong telur 40,92\%, penutup sarang 39,05\%, dan campuran keseluruhan sarang (mix) 42,74\%. Analisis antimikrobia menunjukkan bahwa sarang Trigona spp berpengaruh menghambat pertumbuhan mikrobia patogen uji dengan konsentrasi hambat minimal $1 \%$ (v/v). Senyawa kimia utama sebagai antimikrobia berasal dari asam lemak dan fenol

\section{DAFTAR PUSTAKA}

Alves, M., Fereeira, I., Froufe, H., Abreu, R., Martins, A\&Pintado, M. (2013). Antimicrobial Activity of Phenolic Compound Identified in Wild Mushrooms, SAR Analysis and Docking Studies. Journal of Applied Microbiology ISSN 1364-5072

Atlas, R. (2010). Handbook of Microbiological Media 4th Edition. Washington DC: CRC press Taylor \& Francis Group

Batovska, D., Todorova, I., Tsvetkova, I.,\&Najdenski, H. (2009). Antibacterial Study of The Medium Chain Fatty Acids and Their 1-Monoglycerides: Individual Effects and Synergistic Relationships. Polish Journal of Microbiology, Vol 58, No $1,43-47$

Carlo, G., Mascolo, N. \& Izzo, A. (1999). Flavonoids: Old and New Aspect of A Class of Natural Therapeutic Drugs. Life Science Vol. 65(4): 337-353 Elsevier Science Inc

Contrera, F., Fonseca, V. \& Nieh, J. (2004). Temporal and Climatological influences on Flight Activity in the Stingless bee Trigona hyalinata. Rev Technologia e Ambiente, Criciuma Vol. 1(2): 35-43

Cushnie, T. \& Lamb, A. (2005). Antimicrobial Activity of Flavonoids. International Journal of Antimicrobial Agent 26: 343-356 www.ischemo.org

Desbois, A. \& Lawlor, K. (2013). Antibacterial Activity of Long-Chain Polyunsaturated Fatty Acids against Propionibacterium acnes and Staphylococcus aureus. Journal of Marine Drugs www.mdpi.com/journal/marinedrugs ISSN 1660-3397

Desbois, A. (2012). Potential Applications of Antimicrobial Fatty Acids in Medicine, Agriculture and Other Industries.
Recent Patents on Anti-Infective Drug Discovery Vol 7, No 2 Bentham Science Publisher

Fatoni, A., Artika, I., Hasan, A., Kuswandi. (2008). Activity of Propolis Produced by Trigona spp. Against Campylobacter spp. Journal of Biosciences ISSN: 1978-3019.

Karbara, J., Swieczkowski, D., Conley, A. \& Truant, J. (1972). Fatty Acids and Derivatives as Antimicrobial Agents. Antimicrobal Agent and Chemotherapy American Society for Microbiology

Karlova, T., Polakova, L., Smidrkal, J. \& Filip, V. (2010). Antimicrobial Effects of Fatty Acid Fructose Esters. Csech Journal Food Sci Vol 28 (2): 146-149

Kumar, N., Mueen, A., Dang, R., Shivananda, T., \& Das, K. (2009). GC-MS Analysis of Propolis of Indian Origin. Journal Young Pharm Vol.1 (1): 46-48

Lakshmi, V. \& Bai, V. (2015). Determination of Biologically Active Compound in iClerodendrum phlomidis (L.) Leaf Extract Using GC/MS. International Journal of Multidisciplinary Research and Development 2(1): 294300 www.allsubjectjournal.com

Nitiema, L., Savadogo, A., Simpore, J., Dianou, D. \& Traore, A. (2012). In Vitro Antimicrobial Activity Some Phenolic Compounds (Coumarin and Quercetin) Against Gastroenteritis Bacterial Strains. International Journal of Microbiological Research 3(3): 183-187

Ogoblu, D., Oni, A., Daini, O. \& Oloko, A. (2007). In Vitro Antimicrobial Properties of Coconut Oil on Candida Species in Ibadan, Nigeria. Journal of Medicinal Food 10 (2): $384-387$

Pérez-Pérez, E.M., Suárez, E., Peña-Vera, M.J., González, A.C., Vit, P. (2013). Antioxidant activity and microorganisms in nest products of Tetragonisca angustula Latreille, 1811 from Mérida, Venezuela. pp. 1-8. In Vit P \& Roubik DW, eds. Stingless bees process honey and pollen in cerumen pots. Facultad de Farmacia y Bioanálisis, Universidad de Los Andes; Mérida, Venezuela.

Pohl, C., Kock, K. \& Thibane, V. (2011). Antifungal Free Fatty Acids: A review. Science Againts Microbial Pathogens: Communicating Current Research And Technologi Advances

Pujirahayu, N., Ritonga, H. \& Uslinawaty, Z. (2014). Properties and Flavonoids Content In Propolis of Some Extraction Methode of Raw Propolis. International Journal of Pharmacy and Pharmaceutical Sciencess 6 ISSN.09751491

Ra'ed, J. A, Ibrahim, K. N, Rula, M. D. \& Mosa, A. (2008). Honey Bee Hive Modification for Propolis Collection. Jordan Journal of Agricultural Sciences, Vol 4(2)

Rahmayanti, D., Dharma, A. \& Salim, M. (2013). Fermentasi Anaerob dari Sampah Pasar Untuk Pembentukan Biogas. Jurnal Kimia Unand Vol. 2 (2) ISSN No.2303-3401

Reybroeck, W., Daeseleire, E., Barabander, H \& Herman, L. (2012). Antimicrobials in Beekeeping. Veterinary Microbiology 158 1-11

Rodrigues, M., Santana, W., Freitas, G\&Soares, E. (2007). Flight Activity of Tetragona clavipes at The Sao Paulo 
University Campus in Ribeirao Preto. Biosci, J., Uberlandia vol 23, supplement 1, p. 118-124

Sabir, A. (2005). Aktivitas antibakteri flavonoid propolis Trigona sp terhadap bakteri Streptococcus mutans (in vitro). Makasar: Universitas Hasanudin. Majalah Kedokteran Gigi. (Dent. J.), Vol. 38. No. 3: 135-141

Selvan, A \& Prabhu, T. (2010). Extraction Of Propolis From Beehives And Characterization Of Its Constituents And Medicinal Properties :A Review. International Journal of Advanced Engineering Technology Vol.I/ Issue III/Oct.Dec.,2010/50-53 E-ISSN 0976-3945

Sia, C., Yim, H., Lai, C. (2010). Commercial Virgin Coconut Oil: Assesment of Antimicrobial potential. Asian Journal of Food and Agro-Industry 3(06),567-579 ISSN 1906-3040

Wahyuni, N., Sari, S., Kurniawan, E. (2013). Teknik Produksi Propolis Lebah Madu Trigona Spp di NTB. Laporan Hasil Penelitian Balai Penelitian Teknologi Hasil Hutan Bukan Kayu Mataram 